\title{
Note
}

\section{Observations on the Ichnology of the Meguma Group (? Cambro-Ordovician) of Nova Scotia}

\author{
R.K. Pickerill, Department of Geology, University of New Bmunswick, \\ Fredericton, New Brinswick, Canada E3B $5 A 3$ \\ and
}

$J$. Duncan Keppie, Department of Mines and Energy, 1690 Hollis Street, Halifax, Nova Scotia, Canada B3J $2 \times 1$

\begin{abstract}
The trace fossils Arenicolites variabalis, Circulichnis montanus and Paleodictyon (Glenodictyum) cf. imperfectum from the ?Cambro-Ordovician Meguma Group of Nova Scotia are described in detail. The significance of the occurrence of each of these ichnospecies is also noted. The environmental and stratigraphic ranges of $A$. variabalis are extended respectively to 'deep water' and the Ordovician; the stratigraphic range of $C$. montanus is extended to the Ordovician and its presence in the Meguma Group to date represents the first and only recording of the species in the western hemisphere; $P$. $c f$. imperfectum provides additional evidence that at least part of the Goldenville Formation is Ordovician.
\end{abstract}

On dêcrit en détail les traces fossiles Arenicolites variabalis, Circulichnis montanus et Paleodictyon (GLenodictyum) cf. imperfectum provenant du groupe Meguma (?Cambro-Ordovicien) de la Nouvelle-Ecosse. De plus, 1 'on met en évidence la signification de la présence de chacune de ces ichnoespèces. On étend I'environnement d'A.variabilis jusqu'en 'eau profonde' et sa portée stratigraphique jusqu'à l'ordovicien; la portée stratigraphique de $C$. montanus est étendue à $I^{\prime}$ Ordovicien ét jusqu'à ce jour, le groupe Meguma représente le seul endroit dans l'hémisphère ouest où sa présence est notée; $P$. cf. imperfection fournit une preuve de plus qu'au moins une partie de la formation de Goldenville date de l'ordovicien.

[Traduit par le journal]

\section{INTRODUCT ION}

The ?Cambro-Ordovician Meguma Group of Nova Scotia comprises a thick succession (at least $10,000 \mathrm{~m}$ ) of sandstone, siltstone and shale that was deposited as a turbidite fan complex in either a trough or intradeep (Dewey 1969, Keppie, in press) or as a continental rise prism (Schenk 1970, 1971). The Group has been traditionally subdivided into a lower sandy Goldenville Formation and an upper shaly Halifax Formation. Schenk et al. (1980) have suggested that the formations are at least partly coeval, the former representing mid-fan channelized deposits of a large submarine fan system and the latter interfingering overbank turbidites, contourites and pelagic and hemipelagic deposits deposited between

MARITIME SEDIMENTS AND ATLANTIC GEOLOGY $17,130-138$ (1981) the major channels. Although considerable research has been undertaken by schenk and his colleagues on aspects of the sedimentology of the Meguma Group (e.g. Harris and Schenk 1968, 1975; Schenk 1970, 1978; Schenk et al. 1980) little work has been directed towards the ichnology. Mention has been made in the above papers that the group contains trace fossils at several localities but no detailed examination or interpretation has thus far been attempted. One exception is that of Pickerill and Harris (1979), who re-interpreted the supposedly biogenic sedimentary structure Astropolithon hindii as inorganic in origin. Brief mention of the trace fossils has also been made in Smith (1977) and Pickerill (1980).

The present authors are currently undertaking a more detailed examin- 
ation of the ichnology of the Group and thus far the following ichnogenera have been recorded: Arenicolites, Buthotrephis, Chondrites, Circulichnis, Fucusopsis, Glockerichnus, Gordia, Helminthopsis, Paleodictyon, Phycodes, Planolites and Scalarituka.

As the Meguma Group occupies several thousands of square kilometres of present-day Nova Scotia, the research is by no means complete and is still in its infancy. In view of the nature of some of the recordings made thus far however, we feel it timely to describe and report in this note on the occurrence and significance of three of the ichnogenera, namely Arenicolites, Circulichnis and Palaeodictyon. The importance and relevance of each of these recordings are made apparent in the final section.

\section{SYSTEMATICS}

Ichnogenus Arenicolites Salter, 1857 Arenicolites variabalis Fürsich, 1974 (Figs. 1, 2)

Description: Variable, narrow or wide, vertical or sub-vertical, essentially U-shaped tubes without spreite. Circular tube diameters vary between $7-12 \mathrm{~mm}$ and the distance between the shafts 3-51mm. Maximum observed depth of the tubes was $280 \mathrm{~mm}$. Commonly the two shafts of the U-tube and the U-turn itself are not in the same plane (Fig. 1), a characteristic feature of the species. The course of the shafts may also be variable. Burrow fill is coarse silt and specimens are preserved in full relief.

Remarks: Arenicolites is widely believed to be the domichnia of suspension-feeding polychaete annelids, which, according to Jansa (1974), belong to the family Mochtyellidae. The Meguma representative, A. variabalis, has been recently described by Fürsich (1974) from the Upper Jurassic of southern England. A. variabalis from the Meguma is identical to its Jurassic counterpart except that in the latter, retrusive features are occasionally seen in the U-turn.

Occurrence: Halifax Formation at Blue Rocks, Lunenberg County, $30 \mathrm{~km}$ southwest of Halifax (see Stow and Shanmugan 1980, fig. 1C, p. 28).

Ichnogenus Circulichnis Vialov, 1971 Circulichnis montanus Vialov, 1971 (Fig. 3)

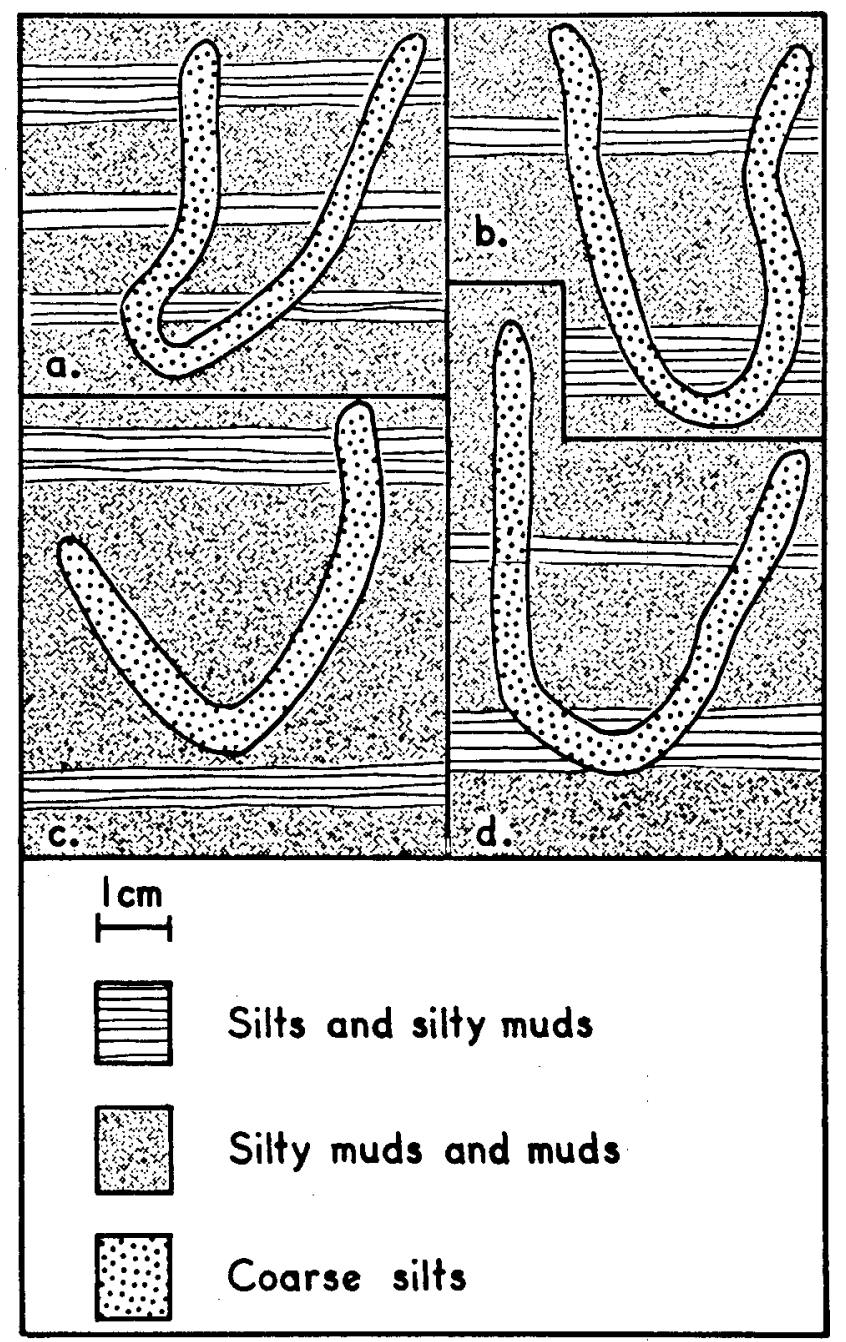

Fig. 1 - Sketch of morphological variation in Arenicolites variabalis in the Halifax Formation at Blue Rocks redrawn from field photographs. Note that in all these specimens the two shafts at the $U$-tube are not in the same plane. 

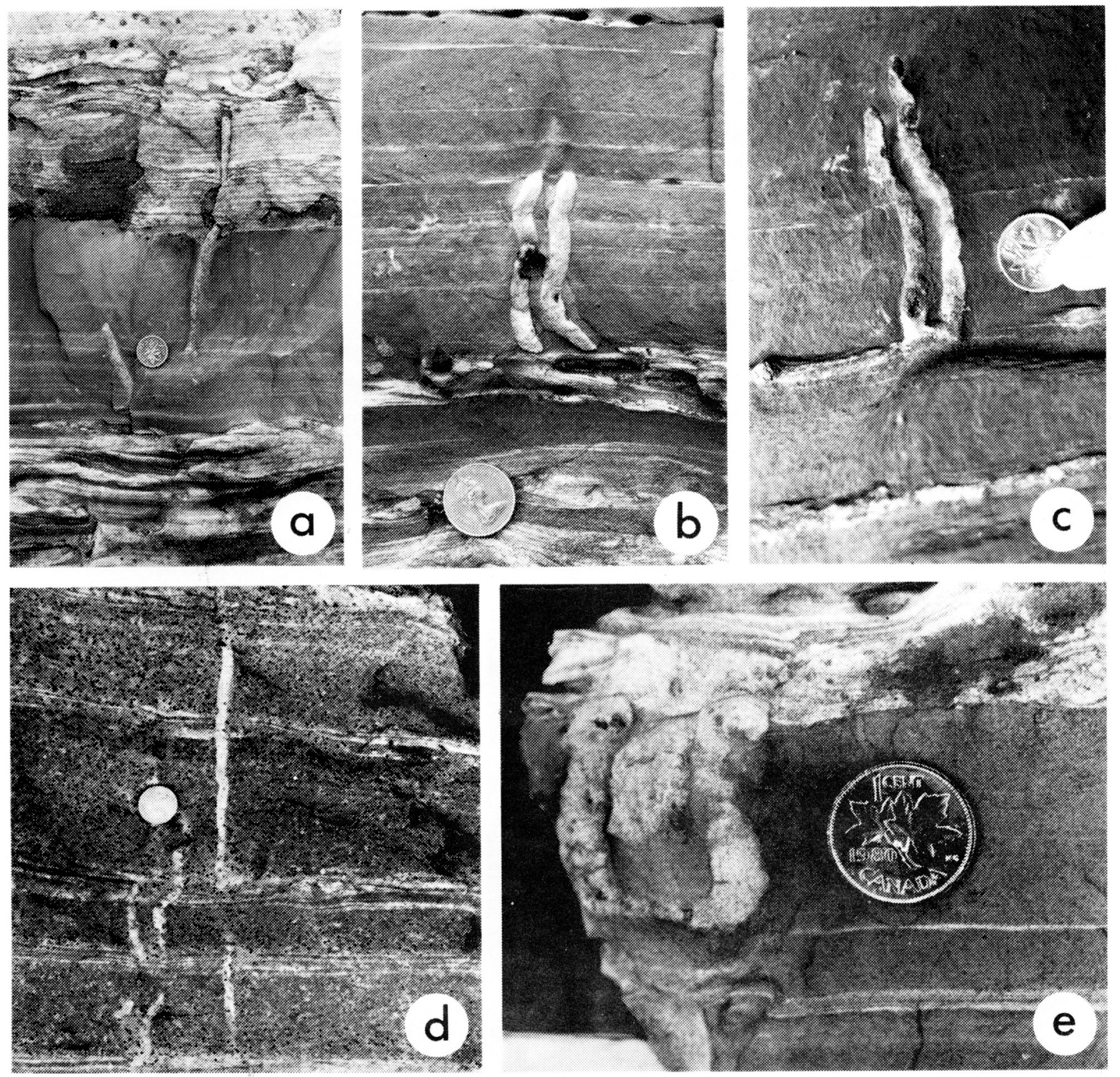

Fig. 2 -Arenicolites variabalis in the Halifax Formation at Blue Rocks. Specimen $e$ courtesy of Dr. P. Schenk. Coin djameter is $1.9 \mathrm{~cm}$.

Description: Tectonically deformed and (now) highly elliptical but regularly shaped (irrespective of size) traces preserved in concave or convex hyporelief on the lower surface of iron-stained slates. Occasional specimens demonstrate that the ellipses represent infaunal burrows of post-depositional origin (now flattened) rather than trails produced at the sediment/waterinterface.

Dimensions of the elliptical burrows are variable with the maximum observed being $152 \times 83 \mathrm{~mm}$ (long $v$ short axis respectively), and the minimum being $32 \times 19 \mathrm{~mm}$. Burrows forming the ellipses possess a flattened diameter of between 3 and $13 \mathrm{~mm}$. This latter parameter, although consistent within a single specimen, does not exhibit any direct relationship with the dimensions of the presently defined elIipse. 

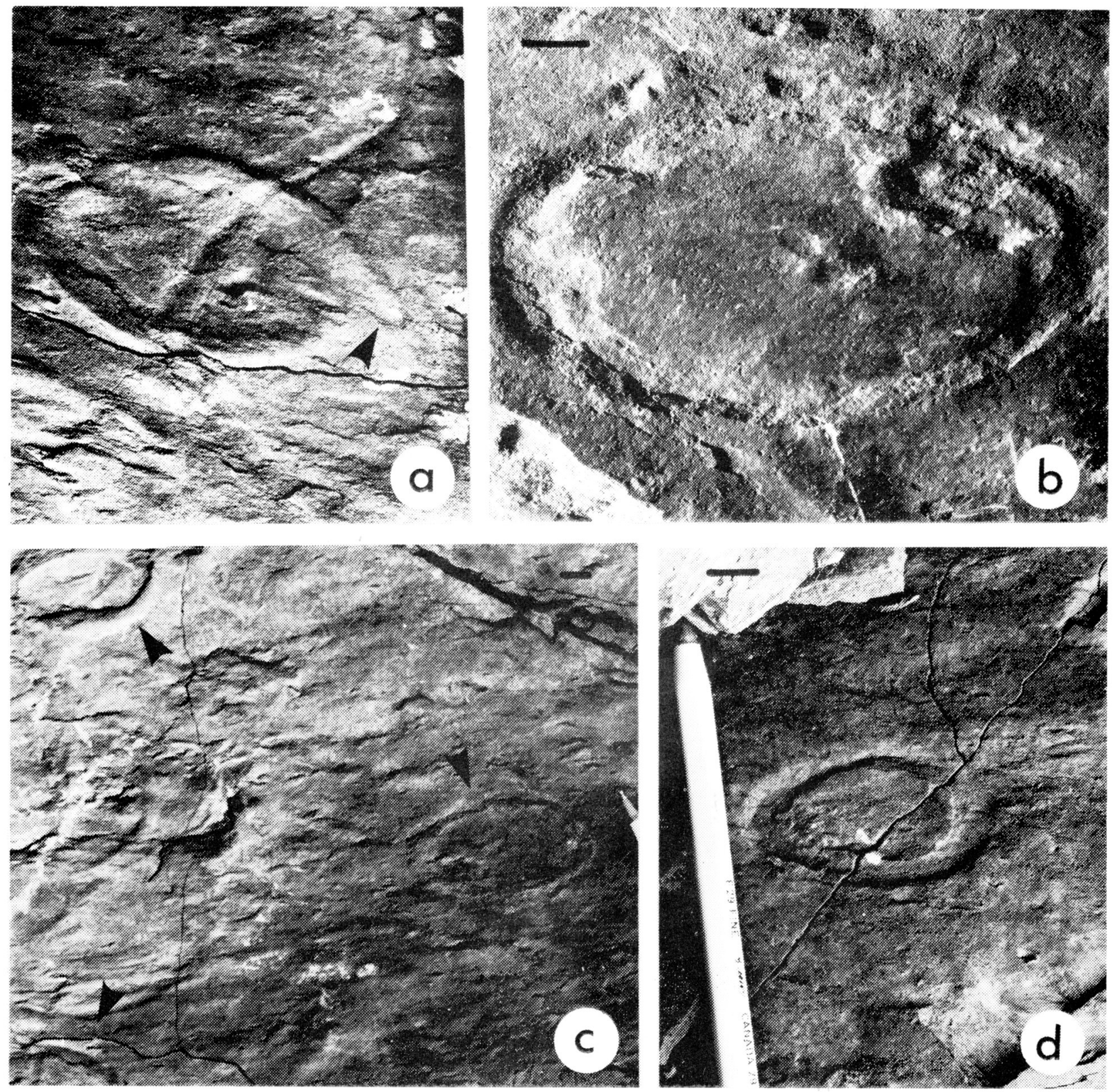

Fig. 3 - Circulichnis montanlis in the Halifax Formation on Highway 101, $1 \mathrm{~km}$ east of Exit 11 to Kentville. Note that specimen $\alpha$ is cut by a Helminthopsis burrow and exhibits a burrow leaving the completed ellipse (arrowed). Specimen $c$ contains three examples of $C$. montanus (arrowed). Bar scale is $1 \mathrm{~cm}$.

Remarks: The traces described herein with Charniodiscus in any sense. were previously interpreted as Char- Instead they are interpreted as niodiscus? by Smith (1977). How-Circulichnis montanus, a monoever, Glaessner (1979) has demon-specific ichnogenus described in a strated that this latter genus is a Russian publication by Vialov (1971) problematical coelenterate of the from the Upper Triassic of the Family Charniidae of restricted southwest Pamirs of central Asia. Precambrian age. Specimens des- Unfortunately Vialov (ibid.) only cribed herein are trace fossils described the holotype in detail sensu stricto and cannot be equated and gave no indication of size vari- 
ation in the Asian material. Nevertheless, several of the Meguma specimens possess approximately similar dimensions to the holotype, with the exception of the diameter of the flattened burrows, which in the Meguma specimens is apparently larger (in the holotype "The width of the cylinder is apparently $1 \mathrm{~mm}$ (0.7-1.5mm)" - Vialov, 1971, p. 91 trans. litt.). In view of the incomplete description of the monospecific ichnogenus, at the present time the Meguma material can best be regarded as conspecific. Strain analysis of the Meguma material undertaken by Smith (1977) has demonstrated that the initial shape of the structures was "circular to slightly elongate" and that the ratio of the long axis to short axis of the initial ellipse was not uniform. This also conforms to the original definition of the type species which is ".... almost round (or oval) in shape...." (Vialov 1971, p. 91 trans. -Eitt.).

Occasional examples of the Meguma material potentially illustrate how the traces were formed. For example, Figure $3 a$ exhibits $C$. montanus with a burrow of Helminthopsis-type leaving the completed ellipse. As suggested by Vialov (ibid.) in specimens, incidentally, where no exit was observed, the producer presumably moved back up or down into the sediment once the 'whorl' was completed. Associated with $C$. montanus on the same bedding plane are many flattened examples (with similar burrow dimensions) of the irregularly meandering burrow Helminthopsis sp. Evidently the producers of $C$. montanus and Helminthopsis sp. were one and the same organism (?annelia), with C. montanus simply representing a specific behavioural variant. In this context it is interesting to note that in Häntzschel (1975), a figured specimen of Helminthopsis sp. (fig. $44,2 a, p . w 71)$ also contains a circular but unnamed burrow, pre- sumeably C. montanus.

Occurrence: Halifax Formation, Highway $101,1 \mathrm{~km}$ east of Exit 11 to Kentville (see Smith 1977, p. 157 for details). The same locality has yielded Tremadocian acritarchs (W.A.M. Jenkins, written communication).

\section{Ichnogenus Paleodictyon Meneghini, 1850 \\ Subichnogenus Glenodictyum \\ Van der Marck, 1863 \\ Paleodictyon (Glenodictyum) of. \\ imperfectum seilacher, 1977}

(Fig. 4)

Description: The trace consists of a regular network of mostly hexagonal but now deformed meshes, each mesh ranging from a maximum of $19 \times 17 \mathrm{~mm}$ to 16 to $13 \mathrm{~mm}$ in diameter. In detail, individual hexagons vary somewhat in both size and shape. Bordering riblets are reasonably consistent in diameter, each being $2-2.5 \mathrm{~mm}$ wide. Crosssectional shape of the riblets is unknown as the specimen is preserved in convex hyporelief. Likewise, whether the system is pre-

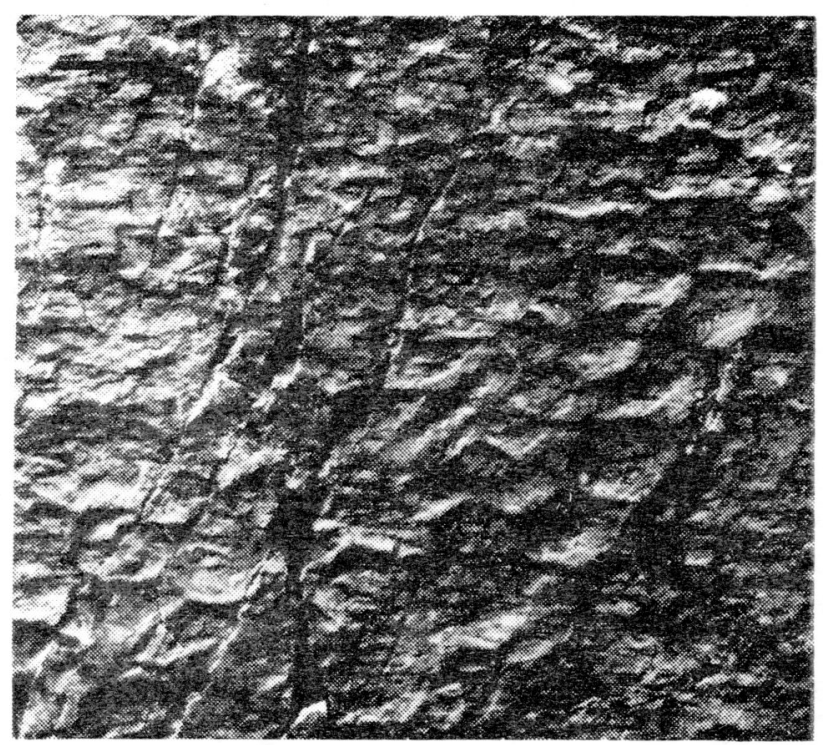

Fig. 4 - Paleodictyon (Glenodictyum) of. imperfectum from the Goldenville Formation, $20 \mathrm{~km}$ north of Halifax. Bar scale is $1 \mathrm{~cm}$. 
or post-depositional in origin also remains an enigma. The complete system is approximately hexagonal in outline, although preservation is incomplete.

Remarks: In view of the approximately uniform hexagonal meshes and approximately hexagonal outline, the specimen can be identified with the subichnogenus Glenodictyum (see Seilacher 1977). As only one specimen has been observed and this itself is somewhat deformed tectonically, the material is only tentatively identified at ichnospecific level as $P$. (Glenodictyum) imperfectum, a species characterized by fairly wide meshes of unequal size and shape. It also resembles $P$. (Glenoảictyum) strozzii Meneghini 1850 but differs in detail from this species in that it does not possess meshes in the order of $10 \mathrm{~mm}$, a characteristic of the latter. The Meguma specimen is also reminiscent of $P$. gomezi Azpeitia 1933 though this species is also characterized by small diameter meshes. The origin of Paleodictyon networks has been extensively discussed by Seilacher (1977), Ksiaźkiewicz (1977) and Kern (1980).

Occurrence: Goldenville Formation, $2 \mathrm{~km}$ south of Halifax International Airport on Route $102,20 \mathrm{~km}$ north of Halifax (Stop 5 on Fig. 4 in Harris (1975) and Stop 7.3 in Rast et al. (1980).

\section{SIGNIF ICANCE}

1. Arenicolites spp. have, somewhat erroneously, been traditionally regarded as specific shallow water marine indicators (see Fürsich 1974, Hakes 1976, and references therein). To date, the only 'deep water' recordings of the ichnogenus have been made by Crimes (1970) from Cambrian turbidites in Eire, Crimes et al. (1974) from Upper Ordovician turbidites in northwest Spain) by Jansa (1974) from Cambro-Ordovician slope deposits of the Cow Head Group, western Newfoundland, and by Crimes (1977) in Eocene mid-fan turbidites from northern spain. In all these examples, 'Arenicolites' was only identified at ichnogeneric level and as descriptions are incomplete additional comment is difficult. However, it must be realized that invertebrate palaeotologists have long recognized that different species of a single genus can potentially possess different ecological preferences (e.g. Hurst 1975). Ichnologists should also recognize this and be encouraged to describe their material more specifically. A. variabalis has only previously been recorded in intertidal or shallow subtidal high energy environments of Upper Jurassic age (Fürsich 1974, 1975). The Meguma recording not only extends its stratigraphic range to Ordovician rocks but also its environmental range to 'deep water' regimes. The Halifax Formation at Blue Rocks has been interpreted to represent basin plain to outer fan deposits by stow and Shanmugan (1980) and as contourites formed by tractional currents by Schenk et al. (1980). The presence of $A$. variabalis favours the latter interpretation because suspension feeders require continual water circulation in order to maintain their existence.

2. Circulichnis montanus has, until now, not been recorded in the western hemisphere and has also only previously been recorded from Triassic rocks. Similar but larger structures have been reported in present-day abyssal plain sediments by Ketcheli et al. (1978) and Kitchell and Clark (1979) who, indeed, compared their material to "Ciculichnus" (sic.). In view of the paucity of recordings it is somewhat premature to predict that the ichnospecies is a specific 
enivornmental indicator. Nevertheless, the only recordings made thus far are all from 'deep water' environments.

3. Species of Paleodictyon are unknown in rocks of Cambrian age, with the earliest recorded specimens being from the ordoviciar of Iraq (Seilacher 1963), eastern Canada (Pickerill 1980) and a possible recording in the United States (Osgood 1970). The age of the Goldenville Formation is poorly resolved, dependent upon poorly preserved graptolites (possibly Didymograptus) of possible Arenigian age reported from near the head of Tangier Harbour, some 50 $\mathrm{km}$ east-northeast of Halifax (Harris and Schenk 1975). If, indeed, Paleodictyon can be regarded, as seems most likely, as a definitive ordovician or younger trace fossil, then this recording adds additional evidence that at least part of the Goldenville Formation is ordovician in age. Unfortunately, the locality is situated only a few tens of metres below the contact of typical Halifax and typical Goldenville lithologies, and therefore the probability still exists that the sequence extends well into the Cambrian.

\section{ACKNOWLEDGEMENTS}

One of us (R.K.P.) wishes to acknowledge N.S.E.R.C. Grant A3857 auring the tenure of which this research was undertaken. Permission for publication was granted to J.D.K. by the Director, Mineral Resources Division, Nova Scotia Dept. of Mines and Energy. We wish to thank Drs. T.L. Harland and $P$. Schenk for their constructive criticisms of the original manuscript.

CRIMES, T.P. 1970. The significance of trace fossils in sedimentology, stratigraphy and palaeoecology with examples from Lower Palaeozoic strata. In Trace fossils. Edited by T.P. Crimes and J. C. Harper. Geological Journal Special Issue Number 3, See1 House Press, Liverpool, pp. 101-126.

CRIMES, T.P., MARCOS, A. and PEREZ-ESTAÚN, A. 1974. Upper Ordovician turbidites in western Asturias: a facies analysis with particular reference to vertical and lateral variations. Palaeogeography, Palaeoclimatology, Palaeoecology, 15, pp. 169-184.

DEWEY, J.F. 1969. Evolution of the Appalachian/Caledonide Orogen. Nature, 222 , pp. 124-129.

FÜRSICH, F. T. 1974. Corallian (Upper Jurassic) trace fossils from England and Normandy. Stuttgarter Beitrage zur Naturkunde, Series B, Number 13, $52 \mathrm{p}$.

1975. Trace fossils as environmental indicators in the Corallian of England and Normandy. Lethaia, 8, pp. 151-172.

GLAESSNER, M. F. 1979. Precambrian. In Treatise on Invertebrate Paleontology, Part A, Introduction. Edited by R.A. Robison and C. Teichert. Geological Society of America, Incorporated and The University of Kansas, pp. A79-A118.

HAKES, W.G. 1976. Trace fossils and depositional environment of four clastic units, Upper Pennsylvanian megacyclothems, northeastern Kansas. University of Kansas Paleontological Contributions, Article 63, 46p.

HÄNTZSCHEL, W. 1975. Trace fossils and problematica. In Treatise on Invertebrate Paleontology, Part W, Miscellanea. Edited by C. Teichert. Geological Society of America, Incorporated and The University of Kansas, pp. W1-W296.

HARRIS, I.M. Editor 1975. Ancient Sediments of Nova Scotia. Eastern Section of the Society of Economic Paleontologists and Mineralogists, Field Trip Guidebook, 123p.

HARRIS, I.M. and SCHENK, P.E. 1968. A Study of Sedimentary Structures in 
the Goldenville Formation, eastern Nova Scotia. Maritime Sediments, 4, pp. 1-4.

Meguma Group. Maritime Sediments, 11 , pp. 25-46.

HURST, J.M. 1975. Wenlock carbonate, level-bottom, brachiopod-dominated communities from Wales and the Welsh Borderland. Palaeogeography, Paleoclimatology, Palaeoecology, 17, pp. 227-255.

JANSA, L.F. 1974. Trace fossils from the Cambro-Ordovician Cow Head Group, Newfoundland, and their paleobathymetric implication. Palaeogeography, Palaeoclimatology, Palaeoecology, 15, pp. 233-244.

KEPPIE, J.D. in press. Tectonic Map of Nova Scotia. Scale 1:500,000. Nova Scotia Department of Mines and Energy.

KERN, J.P. 1980. Origin of trace fossils in Polish Carpathian flysch. Lethaia, 13, pp. 347-362.

KITCHELL, J.A. and CLARK, D.L. 1979. A multivariate approach to biofacies analysis of deep-sea traces from the Central Arctic. Journal of Paleontology, 53, pp. 1045-1067.

KITCHELL, J.A., KITCHELL, J.F., JOHNSON, G.L. and HUNKINS, K.L. 1978. Abyssal traces and megafauna: comparison of productivity, diversity and density in the Arctic and Antarctic. Paleobiology, 4, pp. 171-180.

KSIAZKKIEWICZ, M. 1977. Trace fossils in the flysch of the Polish Carpathians. Palaeontologia Polonica, 36, 208p.

OSGOOD, R.G. 1970. Trace fossils of the Cincinnati area. Paleontographica Americana, 5, pp. 282-444.

FICKERILL, R.K. 1980. Phanerozoic flysch trace fossil diversity - observations based on an Ordovician flysch ichnofauna from the Aroostook-Matapedia Carbonate Belt of northern New Brunswick. Canadian Journal of Earth Sciences, 17, pP. 1259-1270.
PICKERILL, R.K. and HARRIS, I.M. 1979. A reinterpretation of Astropolithon hindii Daws on 1878. Journal of Sedimentary Petrology, 49, pp. 1029-1036.

RAST, N., ST-JULIEN, P., STRINGER, P., PICKERILL, R.K., GRANT, R.H. and KEPPIE, $J$, DUNCAN 1980. The northern Appalachian geotraverse: Quebec-New Brunswick-Nova Scotia. Geological Association of Canada and Mineralogical Association of Canada, Field Trip Guidebook, Trip 3, Halifax '80, 145p.

SCHENK, P.E. 1970. Regional variation of the flysch-1ike Meguma Group (lower Paleozoic) of Nova Scotia compared to Recent sedimentation off the Scotian shelf. In J. Lajoie. (ed) Geological Association of Canada, Special Paper, Number 7, pp. 127-153.

1971. Southeastern Atlantic Canada, northwestern Africa, and continental drift. Canadian Journal of Earth Sciences, 8, pp. 1218-1251.

Canadian Appalachians. In IGCP Project 27, Caledonian-Appalachian Orogen of the North Arlantic Region. Geological Survey of Canada, Paper 78-13, pp. 111-136.

SCHENK, P.E., LANE, T.E. and JENSEN, L. R. 1980. Paleozoic history of Nova Scotia - a time trip to Africa (or South America?). Geological Association of Canada and Mineralogical Association of Canada, Field Trip Guidebook, Trip 20, Halifax '80, 82p.

SEILACHER, A. 1963. Kaledonischer Unterbau der Irakiden. Neues Jahrbuch fuer Geologie and Palaeontologie, Monatschefte, Stuttgart, 10 , pp. 527 . 542 .

1977. Pattern analysis of Paleodictyon and related trace fossils. In Trace fossils 2. Edited by T.P. Crimes and J.C. Harper. Geological Journal Special Issue Number 9, Sẻel House Press, Liverpool, pp. 289-334.

SMITH, P.K. 1977. Strain and trace fossils. In Nova Scotia Department of 
Mines, Report of Activities - 1976. Edited by D.A. Murray, pp. 157-165.

STOW, D.A.V. and SHANMUGAM, G. 1980. Sequence of structures in fine-grained turbidites: comparison of Recent deepsea and ancient flysch sediments. Sedimentary Geology, 25, pp. 23-42.

VIALOV, P.S. 1971. Rare Mesozoic problematica from the Pamir and Caucasus. Paleontologicheskiy Sbornik. Lvov, 7, pp. 85-93. (In Russian).

Reviewers: P.E. Schenk T. Harland 